serie Mental health and economic conditions: How do economic fluctuations influence mental problems? 
Los documentos de trabajo del Ivie ofrecen un avance de los resultados de las investigaciones económicas en curso, con objeto de generar un proceso de discusión previo a su remisión a las revistas científicas. Al publicar este documento de trabajo, el Ivie no asume responsabilidad sobre su contenido.

Ivie working papers offer in advance the results of economic research under way in order to encourage a discussion process before sending them to scientific journals for their final publication. Ivie's decision to publish this working paper does not imply any responsibility for its content.

La Serie AD es continuadora de la labor iniciada por el Departamento de Fundamentos de Análisis Económico de la Universidad de Alicante en su colección "A DISCUSIÓN" y difunde trabajos de marcado contenido teórico. Esta serie es coordinada por Carmen Herrero.

The AD series, coordinated by Carmen Herrero, is a continuation of the work initiated by the Department of Economic Analysis of the Universidad de Alicante in its collection "A DISCUSIÓN", providing and distributing papers marked by their theoretical content.

Todos los documentos de trabajo están disponibles de forma gratuita en la web del Ivie http:/ / www.ivie.es, así como las instrucciones para los autores que desean publicar en nuestras series.

Working papers can be downloaded free of charge from the Ivie website http://www.ivie.es, as well as the instructions for authors who are interested in publishing in our series.

Versión: marzo 2012 / Version: March 2012

Edita / Published by:

Instituto Valenciano de Investigaciones Económicas, S.A.

C/ Guardia Civil, 22 esc. 2 1o - 46020 Valencia (Spain) 


\title{
Mental health and economic conditions: How do economic fluctuations influence mental problems?*
}

\author{
Mariya Melnychuk ${ }^{* *}$
}

\begin{abstract}
This paper seeks to assess how economic fluctuations, measured by changes in the regional unemployment rate, adect mental health of individuals who are currently active in the labor market. We use the UK's 1997-2010 Labour Force Survey to show whether people are more likely to report suffering from mental problems when the economic situation worsens. The results suggest that, when the economic situation deteriorates, employed married men, employed and unemployed married women are more likely to suffer from depression or anxiety, while single unemployed men benefit from living in the higher-unemployment areas.
\end{abstract}

Keywords: mental health, depression, anxiety, macroeconomic conditions, unemployment.

JEL classification: C23, I10, I18, J01.

\footnotetext{
* I gratefully acknowledge the essential comments of M. Dolores Collado Vindel, whose help and inspiration were crucial for doing this research. I appreciated the helpful comments from Climent Quintana-Domeque, Mariano Bosch, Luis Ubeda, Marcos Vera-Hernandez, Tor Iversen and the participants of Alicante Econometric Workshop, Irdes Workshop on Applied Health Economics and Policy Evaluation (Paris), 10th Journees Louis-Andre Gerard-Varet Conference in Public Economics (Marseille), QED Meeting 2011 (Lisbon) and an anonymous referee from IVIE. I also acknowledge the financial support from the Departamento de Fundamentos del Análisis Económico of the Universidad de Alicante.
}

** M. Melnychuk Universidad de Alicante, Facultad de Económicas, Dpto. Fundamentos del Análisis Económico, Carretera de San Vicente s/n, 03080 San Vicente (Alicante), Spain, corresponding author: mariya@ua.es. 


\section{Introduction}

It has been well-established in a series of papers by Ruhm $(2000,2003,2005)$ that human mortality and morbidity are procyclical: a fall in the state unemployment rate is associated with a rise in a state's mortality rates and the probability of reporting one or more acute morbidity or having at least one health problem. While this may be surprising at first glance, it has a quite intuitive explanation (Ruhm, 2003): when the economy performs well and people face better labour market opportunities, the opportunity cost of time rises inducing individuals to invest less in health prevention, such as exercise and healthy lifestyles. On the other hand, people are more involved in risky activities, such as smoking, unhealthy eating, drinking and driving, which are linked to health problems and mortality. Hence, the combination of lower investment into health along with detrimental activities results in poorer health in good times.

The results above suggest that several aspects of people's physical health improves when the economy temporarily deteriorates. And what happens in terms of mental problems? One argument is that economic downturns translated into a higher regional unemployment rate might elevate job insecurity, which raises stress and which may transform into mental disorders. Studies using aggregate data (Tefft, 2011a; Brenner, 1973) have found a positive relationship: as the unemployment rate goes up, mental problems increase. However, there is a problem in using aggregate time-series data, since it may contain factors that are confounded with economic conditions. ${ }^{1}$ These attempts may thus not be appropriate to study the effect of economic conditions on mental health. The question of which impact economic fluctuations have on mental problems of people therefore requires further research using individual data.

The purpose of this study is to analyze the effect of economic conditions on mental health, i.e. whether economic slumps have a measurable cost in terms of an individual's experience of mental problems. A number of papers on happiness has shown that lower individual well-being is related to higher levels of aggregate unemployment (Di Tella et al., 2001; Clark and Oswald, 1994). Ruhm (2003) finds that increases in the unemployment rate are positively associated with the reporting of non-psychotic mental disorders. However, it is important to take into account the individual's employment status when analyzing the effect of economic conditions on mental problems, as employed and unemployed might respond differently to economic downturns. Clark et al. (2009, 2010) suggest that employed people in times of high unemployment experience more pessimistic expectations about their own employment opportunities, which may lead to depression. They might likewise experience involuntary changes in the employment, such as pay cuts or reduced hours which are likely to have a negative impact on mental health as well. With regard the mental health of the unemployed, the effect of surrounding unemployment is slightly different. High unemployment lowers their employment opportunities, however they may benefit from a 'social-norm effect' (Clark, 2003): as the percentage of unemployed people in the close environment increases, one's non complying with the norm becomes less suppressing.

\footnotetext{
${ }^{1}$ For instance, when analysing the effect of economic slumps on mental hospital admissions, Brenner (1973) does not account for changes in hospital capacity (and related factors), admission policy and access to hospital facilities. In Tefft (2011a), greater searching for items "depression" and "anxiety" in Google in the recent Great Recession could reflect wider use of the Internet or the popularity of this search engine (in particular for job search).
} 
When including one's employment status, we have to be aware that own unemployment and mental health are related in at least three different ways (Warr et al., 1998). First, being unemployed may affect mental health. Studies of the Great Depression (Eisenberg and Lazarsfeld, 1938) and of more current data (Clark and Oswald, 1994; Björklund, 1985) identified detrimental psychological effects associated with own unemployment. Theodossiou (1998) finds that joblessness is associated with a marked rise in anxiety, depression and loss of self-confidence, and these psychological consequences are significantly higher even when unemployed individuals are compared with individuals in low-wage employment. Second, mental health is also likely to have an impact on own employment. It could be harder for a depressed individual to enter the job market, as mental problems are likely to affect the intensity and quality of her job search, performance and ability to attend the the interviews (Warr et al., 1998). Furthermore, the employer might be less willing to hire her, since being depressed may involve more sick leave thus reducing productivity or have other direct effects on labour market performance (British Psychological Society, 2011). Third, there may be other individual unobservable factors affecting both, such a general frailty frailty, other genetic factors (Schmitz, 2011) or substance abuse.

We therefore propose to use unemployment due to layoffs which are not related to mental health problems in order to account for those channels (following Schmitz, 2011; and partially Kuhm, 2009). In general it is difficult to obtain data with information on the reason for layoffs. However the data we use, the UK's Labour Force Survey, does contain this information. In combination, our approach differs from the existent literature in three ways. First, we introduce own employment status into Ruhm's model, and thus attempt to separate the effect of the economic conditions on mental problems for the employed and unemployed. Second, we aim to account for the endogeneity of own employment status. Without this, the effect on mental health of the unemployed is probably measured inappropriately which affects the efficiency of policies designed to maintain the mental health of individuals in recessions. Third, the effect might differ by marital status as different family responsibilities are involved and we therefore analyze married and single individuals separately.

The results suggest all but unemployed men are more likely to suffer from mental problems when the economic situation worsens: the increase in the regional unemployment rate is associated with a rise in the probability of suffering from depression or anxiety. On the contrary, but consistent with previous findings, unemployed men suffer from depression less in bad times. When married and single individuals are analysed separately, we discover that single unemployed men even benefit from living in high-unemployment regions: when the economy performs poorly, their probability of having a mental problem declines. Unemployed married women have twice as greater probability as employed single women of suffering depression in economic downturns. Employed married men and women show very similar probabilities of experiencing depression or anxiety in an economic downturn. In order to support the robustness of the results, we perform several checks, including checking the correction for endogeneity, checking for possible migration and contemporaneous effects.

The rest of the paper is organized as follows. Section 2 sets out the intuition regarding the model applied in this work. Section 3 describes the dataset. Section 4 provides the results. Section 5 proposes some robustness checks, and Section 6 concludes. Appendix contains all the relevant tables. 


\section{Econometric specification}

Let $D_{i j t}^{*}$ be an unobservable continuous latent variable which measures mental problems. We also define two dummies, $E_{i j t}$ and $U_{i j t}$, one for being employed and another for being unemployed and interact each of them with the gender-specific unemployment rate in a region $j$ at time $t, U R_{j t}$. We then consider the following model to evaluate the effect of economic conditions on mental problems:

$$
D_{i j t}^{*}=\alpha_{t}+Q_{t}+R_{j}+\rho E_{i j t} * U R_{j t}+\delta U_{i j t} * U R_{j t}+\gamma U_{i j t}+X_{i j t}^{\prime} \beta+u_{i j t}
$$

where $\alpha_{t}$ is a year-specific intercept, $Q_{t}$ is a quarter-specific intercept, $R_{j}$ is a region fixed-effect. Terms $E_{i j t} * U R_{j t}$ and $U_{i j t} * U R_{j t}$ are the interactions of $E_{i j t}$ and $U_{i j t}$ with $U R_{j t}$ and state for the effects of the regional unemployment rate for the employed and unemployed respectively. $X_{i j t}$ is a vector of personal characteristics of individual $i$ living in the region $j$ at time $t, u_{i j t}$ is a disturbance term.

Economic conditions influence employed people's mental problems through $\rho$. If a bad economic situation, i.e. a high regional unemployment rate, induces depression, $\rho$ should be positive, $\rho>0$. Well-being literature (Clark et al. 2009, 2010) emphasizes that employed people in times of high unemployment experience greater job insecurity due to more pessimistic expectations about their own employment opportunities or they may remain in unsatisfactory jobs that they would otherwise have likely left had labour market conditions been better. These circumstances might induce depression and anxiety. For example, Hartley et al. (1991), in their survey on job insecurity, found that depression increases proportionately to the level of job insecurity. Based on the National Alliance on Mental Illness Survey (2009), Roy-Bujnowski (2011) reports that employment in an uncertain economy is not always a protective factor against mental health problems. The employed could experienced involuntary changes in the employment, such as pay cuts or reduced hours. As a result, these individuals are likely to suffer depression or some other form of a mental health problem.

The situation is different for the unemployed. On the one hand, they could also be more depressed in bad times, as their chances of finding a job lowers substantially. On the other hand, the social pressure on the unemployed is lower when there is greater unemployment. As Clark (2003) has suggested, unemployment may have less impact on the unemployed the more they see of it around them, as the stigma from their own unemployment is then reduced. One explanation could be that it is easier for the unemployed to establish social connections when others in the local area are also unemployed (Kessler et al. 1988). There could also be greater emotional support for the unemployed, as more people share the same economic situation. As Jackson and Warr (1987) suggest lower levels of psychological distress among unemployed from areas of chronically high unemployment compared to unemployed living in areas of low unemployment perhaps reflect better adaptation through networks, community solidarity and lower costs of living in areas with higher unemployment. Cohn (1978) finds that the individual feel fells self-dissatisfied to a smaller extent if she can attribute her change in employment status (becoming unemployed) due to some external cause, and the high level of regional unemployment might be such an external cause. Hence we expect the effect for unemployed $(\delta)$, at least for some groups, to be smaller than $\rho$, or even negative, $\delta<0$.

Ideally, we would like to know which individuals became unemployed not as a result 
of deteriorating mental health, i.e. to distinguish all people who first become unemployed from those who first suffered mental problem, and then became unemployed. Unfortunately, perfect information is not available on the timing of individual's unemployment with respect to the onset of mental problems. Indeed, even if this question is put to the individual, it is not clear if she would be able to tell us for sure what happened first. However we might consider situations where unemployment is not driven by individuals' mental health status. One such example is if a person became unemployed due to redundancy. The main assumption here is that workers who were made redundant lose their job for reasons unrelated to mental health, while other job separation could result from reasons connected to mental health (Browning et al. 2006). We thus identify the effect for those unemployed who lose their jobs regardless of their mental problems. ${ }^{2}$ In the UK, redundancy is defined as "dismissal for a reason not related to the individual concerned or for a number of reasons all of which are not so related", i.e. dismissals which are not related to the conduct or capability of the individuals. ${ }^{3}$ It may be the case that the jobs of some or all of a firm's employees become redundant. This could be because the business stops trading, relocates or employees carry out work that is no longer necessary - for example, due to the introduction of new technology. There are certain selection criteria which the employer cannot use as grounds for redundancy, i.e. such a dismissal will be recognized by a tribunal as automatically unfair. One such unfair criterion is "taking actions on specified health and safety grounds". Hence mental health problems cannot be grounds for an individual to be made redundant. ${ }^{4}$

We first estimate our model including all unemployed people using probit with robust standard errors. ${ }^{5}$ We then attempt to correct the model for endogeneity by redefining $U_{i j t}$ (and $E_{i j t}$ respectively) equal to 1 if the individual $i$ is unemployed due to redundancy and 0 if she is employed (equal to 1 if the individual is employed and 0 if she is unemployed due to redundancy).

\section{Data}

The dataset used in this paper comes from the Labour Force Survey (LFS). ${ }^{6}$ It is a quarterly sample survey of households living at private addresses in Great Britain. It is conducted by the Office for National Statistics (ONS). ${ }^{7}$ LFS is the biggest nationally representative regular survey in the UK which provides a rich and vital information on the labour force. Its sample size is of approximately 500, 000 people per year. LFS also contains information on the respondents' economic activity, education, health, family structure, housing information and demographic details. Since the 1997 spring quarter,

\footnotetext{
${ }^{2}$ This approach is similar to Schmitz (2011). Please refer to Morris \& Cook (1991) for an exhaustive review of earlier literature.

${ }^{3}$ http://www.businesslink.gov.uk. For more information see Department for Work and Pension webpage, http://www.dwp.gov.uk/

${ }^{4}$ It is worth noting that redundancy notification should be made within a 30 to 90 -day period prior to the first redundancy (depending on the number of redundancies). This ensures that an unemployment notification happens prior to possible depressive reaction.

${ }^{5}$ Following Ruhm (2005) we use heteroskedasticity-robust standard errors, clustered by region, year and quarter.

${ }^{6}$ http://www.esds.ac.uk/government/lfs/

${ }^{7}$ http://www.statistics.gov.uk/default.asp
} 
all individuals have been asked about particular health problems they may have. We use data from the first quarter of 1997 to the fourth quarter of 2010. The analysis refers to individuals aged 25 to 54 of both genders who are active in the labour force (either employed or unemployed). ${ }^{8}$ This produces $1,182,790$ observations in total, from 83,750 in 1997 to 70, 167 in 2010. 1, 131, 880 individuals are employed, and 50,910 are unemployed, giving an average unemployment rate over the fourteen years of $4.30 \%$. As the labour market may function differently for male and female, we perform a separate analysis for each gender. Hence we have 550,661 males, and 632, 129 females.

As a proxy for mental problems we use the question "Do you have depression, bad nerves or anxiety?" with the option of answering "yes" or "no". This question was chosen because anxiety and depression are the most common mental health disorders in the UK (ONS Psychiatric Morbidity report, 2000). ${ }^{9}$ The same question is contained in the other nationally representative database, the British Household Panel Survey (BHPS) and has been used to study mental health and state transfers (Whittaker and Sutton, 2010), and the impact of working shifts on mental health (Bara and Arber 2009). Hence, we deem it to be a reliable measure of mental problems.

The main proxy for economic conditions is the seasonally adjusted gender specific regional unemployment rate during the three months ending with the survey month (following Ruhm, 2005). ${ }^{10}$ A high unemployment rate is a signal of economic downturns in most people's understanding. If we look at the Great Depression or recent the "Great Recession", both were accompanied by a huge drop in employment. Mental problems, such as depression or anxiety, can be a result of an individual's reflections on the circumstances in which she lives. ${ }^{11}$ Hence, if she feels insecure when the unemployment rate rises, it might stimulate depressive thoughts and provoke mental problems. Furthermore, the unemployment rate is widely broadcast in the mass-media and during an economic downturn people are therefore constantly under the pressure of the news about the economic instability which may also have an impact on their mental problems. The quarterly data of the regional unemployment figures are taken from NOMIS, ${ }^{12}$ which is a service provided by the ONS, to give free access to the most detailed and up-to-date UK labour market statistics from official sources. Micro and macro data are combined with three months difference as the official unemployment figures are published with a quarterly lag.

\footnotetext{
${ }^{8}$ Since the particular interest is to investigate how economic fluctuations, which are reflected in changes in the regional unemployment rate, affect people, we focus on currently economically active individuals. Moreover, we focus on individuals aged 25-54 in order to avoid confoundings with educational and retirement decisions, since, when employment opportunities are low, young people may decide to stay at school longer (or return to education), while people about to retire may opt for early retirement.

${ }^{9}$ Psychiatric morbidity among adults living in private households, 2000 (www.statistics.gov.uk/products/p8258.asp). Mixed anxiety and depression, according to the ONS 2000 survey, is experienced by $9.2 \%$ of adults in UK. This is followed by general anxiety at $4.7 \%$ and depression at $2.8 \%$.

${ }^{10}$ Since the probability of becoming unemployed is different depending on the educational level of the individual (Nickell, 1979), regional unemployment rate should also be defined within educational dimension. Unfortunately, the ONS does not provide information about regional unemployment rates by educational attainment.

${ }^{11}$ The National Health Service (http://www.nhs.uk/) provides some causes of depression, such as stress due to redundancy, job insecurity etc. British Association for Counselling \& Psychotherapy (http://www.bacp.co.uk/) reports that "increases in depression over the last few years may be the collateral damage of the financial crisis and the battle against debt".

${ }^{12}$ https://www.nomisweb.co.uk/
} 
For example, the individual interviewed in the third quarter observes data from the second quarter. ${ }^{13}$ The evolution of the quarterly unemployment rate by region over time is set out in the Appendix.

The LFS also provides detailed information related to the respondent's employment status. The respondent is asked about current economic activity (employed, ILO unemployed or inactive). If she is unemployed, the reason and the duration of unemployment are specified. ${ }^{14}$ This paper explores unemployment due to redundancy as an exogenous shock to employment. The idea is that the experience of being made redundant strongly disrupts a worker's employment career, but workers' mental health is unlikely to cause a firm to decide to make an employee redundant. If the respondent became unemployed in the last three months, she is additionally asked whether it happened due to the firm closing down, downsizing the staff or for another reason. While redundancy does not obviously mean that the firm stopped operating, becoming unemployed due to plant closure is a subsample of redundant people. Checking whether the results obtained for all redundant workers hold for this subsample is part of the robustness checks.

We take regions to mean the 11 Government office regions: North West, North East, Yorkshire and The Humber, East Midlands, West Midlands, East, London, South East, South West, Wales and Scotland. We use individual characteristics as controls, such as age in years and its square, six categorical variables for educational levels: "degree", which includes people having at least a Bachelor's degree, "higher", which includes people having completed higher education, "A-level", which includes GCE A-level or equivalent, "O-level", which consists of GCSE grade A-C or equivalent, "oqlif", people having other qualifications, and the reference group of "no qualification"; two indicators of marital status: "married" which includes married and living as a couple, and "never married" as the reference group; ${ }^{15}$ a dummy variable for having children. We also include 14 year dummies with reference 1997, 11 region dummies with reference London, and 4 quarter dummies with the first quarter being the reference. Descriptive statistics are presented in Table 1.

\footnotetext{
${ }^{13}$ Another reason is that chronic diseases such as anxiety and depression, in general, have no immediate onset. Hence if they need time to develop this is captured by including the unemployment rate from the previous quarter. The unemployment rates are correlated across periods and today's rate somehow reflects yesterday's rate. Therefore, our results might capture the effect of an economic situation over longer than just a quarter period. For example, correlations between the quarterly unemployment rate and the average during a year concluding with the survey month are 0.965 for men and 0.951 for women. The robustness checks analyze the model with different specification to ensure that the results are robust.

${ }^{14}$ The reasons are "dismissed", "made redundant/took voluntary redundancy", "temporary job finished", "resigned", "gave up work for health reasons", "took early retirement", "retired" (at or after state pension age), "gave up for family or personal reasons", "other reason".

${ }^{15}$ Horwitz et al. $(1991,1996)$ provided evidences that marriage is a protective factor against depression. The analysis thus focuses on married vs. never married individuals. Widowed, divorced and separated individuals, which account for $13.3 \%$ of men and $18.48 \%$ of women, are dropped from the sample.
} 
Table 1. Summary statistics

\begin{tabular}{|c|c|c|c|c|c|c|c|c|}
\hline \multirow[b]{2}{*}{ Sample } & \multicolumn{4}{|c|}{ Male } & \multicolumn{4}{|c|}{ Female } \\
\hline & Mean & Std.dev. & Min & Max & Mean & Std.dev. & Min & $\operatorname{Max}$ \\
\hline Depression/Anxiety & 1.12 & 1.05 & 0 & 1 & 1.53 & 1.22 & 0 & 1 \\
\hline Unemployment rate (regional) & 6.35 & 1.94 & 2.9 & 12.7 & 5.08 & 1.27 & 2.2 & 9.5 \\
\hline Unemployment rate (in sample) & 4.96 & 2.17 & 0 & 1 & 3.73 & 1.89 & 0 & 1 \\
\hline Age & 39.3 & 8.43 & 25 & 54 & 39.2 & 8.29 & 25 & 54 \\
\hline Married & 64.6 & 4.78 & 0 & 1 & 70.9 & 4.54 & 0 & 1 \\
\hline Single & 35.3 & 4.78 & 0 & 1 & 29.1 & 4.54 & 0 & 1 \\
\hline Degree & 25.7 & 4.36 & 0 & 1 & 22.6 & 4.18 & 0 & 1 \\
\hline Higher & 10.2 & 3.03 & 0 & 1 & 12.6 & 3.32 & 0 & 1 \\
\hline Alevel & 27.9 & 4.48 & 0 & 1 & 16.7 & 3.73 & 0 & 1 \\
\hline Olevel & 17.1 & 3.76 & 0 & 1 & 27.4 & 4.46 & 0 & 1 \\
\hline Other qualification & 11.9 & 3.24 & 0 & 1 & 11.9 & 3.23 & 0 & 1 \\
\hline No qualification & 6.91 & 2.53 & 0 & 1 & 8.45 & 2.78 & 0 & 1 \\
\hline Having a child & 41.4 & 4.92 & 0 & 1 & 48.8 & 4.99 & 0 & 1 \\
\hline $\mathrm{N}$ & \multicolumn{4}{|c|}{550,661} & \multicolumn{4}{|c|}{632,129} \\
\hline
\end{tabular}

The mean probability of depression is greater for women then for men, which is in line with medical evidence. The mean unemployment rate is higher for men than for women, there is a slight difference between unemployment rates in the sample and from NOMIS, since the later are seasonally adjusted, and are calculated for the economically active population aged 16 and over. The mean age is around 39 years, married individuals constitute $64.6 \%$ and $71 \%$ of men and women sample respectively. There are more men than women with a degree or A-level, while more women have completed higher education, O-level or no qualification. More women than men have at least one child, as very few single men report having children.

\section{Results}

The results are summarized in Tables 2.1. and 2.2. ${ }^{16}$ The reported coefficients are marginal effects for probit models where the dependent variable is an indicator whether the respondent has depression, anxiety, bad nerves or not. For both "All Unemployed" and "Unemployed due to Redundancy" specifications indicator variables for region, year, and quarter are included, and heteroskedasticity-robust standard errors, clustered by region, year and quarter, are reported in parentheses. The main findings suggest that the worsening of economic conditions has a significant detrimental effect on the mental health of the employed: an increase in regional unemployment rate is associated with an increase in the probability to report mental problems. It is consistent with previous findings by Ruhm (2003), Teff (2011a, 2011b). More precisely, when the regional unemployment rate increase by 1 percentage point, the probability of suffering depression increases for the employed men by 0.031 and for the employed women by 0.057 percentage points. This is in line with medical reports which suggest that depression and anxiety are more common in women than men. ${ }^{17}$

\footnotetext{
${ }^{16}$ The column "All Unemployed" refers to the case when all the unemployed are included in the regression, while the column "Unemployed due to Redundancy" presents the results from the regressions with unemloyed due to redundancies only. We present here the marginal effects. The estimated coefficients from probit models are given in the Appendix.

${ }^{17}$ These disparities may be due to women, when asked, being more likely to report symptoms of depression (National Statistics, 2003), while depression in men may have been under diagnosed because
} 
One of our main goals was to assess whether economic conditions affect the unemployed differently from the employed. It should first be noted that being unemployed significantly increases the probability of having mental problems. However, one should control for its endogeneity, otherwise the marginal effect of being unemployed is overestimated. For example, it is lower for men and becomes not significant for women when we control for the reason of being unemployed than if all the unemployed are included in the model. These findings are consistent with Khun et. al (2009) who find a significant increase in the prescriptions of antidepressants for male (but not for women) in a year after plant closure. Moreover, job loss results in an increase in hospitalizations for mental health reasons only in the case of men.

The results also show that economic conditions influence the unemployed differently. For unemployed women the rise in the regional unemployment rate of $1 \mathrm{pp}$ increases the probability of depression by $0.15 \mathrm{pp}$, which is almost three times higher than for employed women. For unemployed men, the coefficient is negative and not statistically significant, confirming the hypothesis that the unemployed could have less mental problems in bad times: less social pressure for being unemployed in high unemployment times counteracts the adverse effect of a bad economic situation. Our results are in line with Clark et al. (2009) findings for German data which report that unemployed men are significantly less negatively affected by regional unemployment than employed men. For women in their study, however, no such offsetting effect appears to exist. Jackson and Warr (1987) for UK also report lower levels of psychological distress among unemployed men from areas of chronically high unemployment than among unemployed men living in areas of low unemployment.

Being married is a strong counteractive factor of one's probability to suffer depression. It is of interest to see whether married and single individual's mental health respond differently to economic conditions. For instance, married employed men could feel depressed when the economy performs badly, as they are financially responsible for their families compared to single men. On the contrary, married women could feel less anxious about economic downturns compared to single, because they may not be the main breadwinners in the household or have their working preference distorted by the trade-off between time for children or husband and work (Simon 1997).

they present to their General practitioner with different symptoms. (National Institute For Clinical Excellence, 2003). However it is true that women are twice as likely to experience anxiety as men. (The Office for National Statistics Psychiatric Morbidity report, 2001). The reasons for this are unclear, but are thought to be due to both social and biological factors. 
Table 2.1. Results: Marginal Effects. Male

\begin{tabular}{|c|c|c|c|c|c|c|c|c|c|c|}
\hline \multirow{3}{*}{$\begin{array}{l}\text { Reg. unemployment rate } \\
\text { (Employed) }\end{array}$} & \multicolumn{5}{|c|}{ All Unemployed } & \multicolumn{5}{|c|}{ Unemployed due to Redundancy } \\
\hline & $0,00038^{* *}$ & $0,00038^{* *}$ & $0,00039^{* * *}$ & $0,00037^{* * *}$ & $0,00037^{* * *}$ & $0,00031^{* *}$ & $0,00031^{* *}$ & $0,00032^{* *}$ & $0,00031^{* *}$ & $0,00031^{* *}$ \\
\hline & $(0,00015)$ & $(0,00015)$ & $(0,00015)$ & $(0,00014)$ & $(0,00014)$ & $(0,00015)$ & $(0,00014)$ & $(0,00014)$ & $(0,00014)$ & $(0,00014)$ \\
\hline Reg. unemployment rate & $-0,00031$ & $-0,00029$ & $-0,00031^{*}$ & $-0,00029$ & $-0,00028$ & $-0,00029$ & $-0,00022$ & $-0,00024$ & $-0,00022$ & $-0,00021$ \\
\hline (Unemployed) & $(0,00019)$ & $(0,00019)$ & $(0,00019)$ & $(0,00018)$ & $(0,00018)$ & $(0,00033)$ & $(0,00032)$ & $(0,00032)$ & $(0,00031)$ & $(0,00031)$ \\
\hline \multirow[t]{2}{*}{ Unemployment dummy } & $0,06363^{* * *}$ & $0,06491^{* * *}$ & $0,06189 * * *$ & $0,05342^{* * *}$ & $0,05339 * * *$ & $0,03382^{* * *}$ & $0,03151^{* * *}$ & $0,03003^{* * *}$ & $0,02579^{* * *}$ & $0,02583^{* * *}$ \\
\hline & $(0,00657)$ & $(0,00666)$ & $(0,00643)$ & $(0,00581)$ & $(0,00581)$ & $(0,00972)$ & $(0,00920)$ & $(0,00893)$ & $(0,00810)$ & $(0,00811)$ \\
\hline \multirow[t]{2}{*}{ Age } & & $0,00079^{* * *}$ & $0,00075^{* * *}$ & $0,00119^{* * *}$ & $0,00140 * * *$ & & $0,00058^{* * *}$ & $0,00054^{* * *}$ & $0,00100 * * *$ & $0,00115^{* * *}$ \\
\hline & & $(0,00015)$ & $(0,00015)$ & $(0,00015)$ & $(0,00015)$ & & $(0,00016)$ & $(0,00016)$ & $(0,00016)$ & $(0,00016)$ \\
\hline \multirow[t]{2}{*}{ Age2 } & & $-0,00001^{* * *}$ & $-0,00001^{* * *}$ & $-0,00001^{* * *}$ & $-0,00001^{* * *}$ & & $-0,00001^{* * * *}$ & $-0,00001^{* * *}$ & $-0,00001^{* * *}$ & $-0,00001^{* * *}$ \\
\hline & & $(0,00000)$ & $(0,00000)$ & $(0,00000)$ & $(0,00000)$ & & $(0,00000)$ & $(0,00000)$ & $(0,00000)$ & $(0,00000)$ \\
\hline \multirow[t]{2}{*}{ Education: Degree } & & & $-0,00355^{* * *}$ & $-0,00327^{* * *}$ & $-0,00330^{* * *}$ & & & $-0,00354^{* * *}$ & $-0,00326^{* * *}$ & $-0,00327^{* * *}$ \\
\hline & & & $(0,00043)$ & $(0,00042)$ & $(0,00042)$ & & & $(0,00043)$ & $(0,00042)$ & $(0,00042)$ \\
\hline \multirow[t]{2}{*}{ Education: Higher } & & & $-0,00265^{* * *}$ & $-0,00221^{* * *}$ & $-0,00222^{* * *}$ & & & $-0,00264^{* * *}$ & $-0,00223^{* * *}$ & $-0,00223^{* * *}$ \\
\hline & & & $(0,00044)$ & $(0,00045)$ & $(0,00044)$ & & & $(0,00043)$ & $(0,00043)$ & $(0,00043)$ \\
\hline \multirow[t]{2}{*}{ Education: Alevel } & & & $-0,00350^{* * *}$ & $-0,00306^{* * *}$ & $-0,00308^{* * *}$ & & & $-0,00380^{* * *}$ & $-0,00338^{* * *}$ & $-0,00339^{* * *}$ \\
\hline & & & $(0,00041)$ & $(0,00041)$ & $(0,00041)$ & & & $(0,00041)$ & $(0,00041)$ & $(0,00041)$ \\
\hline \multirow[t]{2}{*}{ Education: Olevel } & & & $-0,00101^{* *}$ & $-0,00075$ & $-0,00076$ & & & $-0,00131^{* * *}$ & $-0,00104^{* *}$ & $-0,00104^{* *}$ \\
\hline & & & $(0,00050)$ & $(0,00049)$ & $(0,00049)$ & & & $(0,00048)$ & $(0,00048)$ & $(0,00048)$ \\
\hline \multirow[t]{2}{*}{ Education: Other } & & & $-0,00120^{* *}$ & $-0,00074$ & $-0,00076$ & & & $-0,00146^{* * *}$ & $-0,00103^{* *}$ & $-0,00104^{* *}$ \\
\hline & & & $(0,00052)$ & $(0,00053)$ & $(0,00052)$ & & & $(0,00051)$ & $(0,00051)$ & $(0,00051)$ \\
\hline \multirow[t]{2}{*}{ Married } & & & & $-0,00667^{* * *}$ & $-0,00570^{* * *}$ & & & & $-0,00610^{* * *}$ & $-0,00545^{* * *}$ \\
\hline & & & & $(0,00032)$ & $(0,00034)$ & & & & $(0,00032)$ & $(0,00034)$ \\
\hline \multirow[t]{2}{*}{ Children dummy } & & & & & $-0,00161^{* * *}$ & & & & & $-0,00109^{* * *}$ \\
\hline & & & & & $(0,00029)$ & & & & & $(0,00028)$ \\
\hline $\mathrm{N}$ & & & 550,661 & & & & & 531,133 & & \\
\hline
\end{tabular}


Table 2.2. Results: Marginal Effects. Female

\begin{tabular}{|c|c|c|c|c|c|c|c|c|c|c|}
\hline \multirow{3}{*}{$\begin{array}{l}\text { Reg. unemployment rate } \\
\text { (Employed) }\end{array}$} & \multicolumn{5}{|c|}{ All Unemployed } & \multicolumn{5}{|c|}{ Unemployed due to Redundancy } \\
\hline & $0,00057^{*}$ & $0,00060^{*}$ & $0,00060^{*}$ & $0,00061^{* *}$ & $0,00060^{* *}$ & $0,00057^{*}$ & $0,00059^{*}$ & $0,00058^{*}$ & $0,00058^{*}$ & $0,00057^{*}$ \\
\hline & $(0,00032)$ & $(0,00032)$ & $(0,00031)$ & $(0,00030)$ & $(0,00030)$ & $(0,00031)$ & $(0,00031)$ & $(0,00031)$ & $(0,00030)$ & $(0,00030)$ \\
\hline Reg. unemployment rate & 0,00040 & 0,00043 & 0,00034 & 0,00030 & 0,00031 & $0,00149^{*}$ & $0,00156^{*}$ & $0,00144^{*}$ & $0,00148^{*}$ & $0,00150^{*}$ \\
\hline (Unemployed) & $(0,00043)$ & $(0,00042)$ & $(0,00042)$ & $(0,00041)$ & $(0,00041)$ & $(0,00089)$ & $(0,00088)$ & $(0,00087)$ & $(0,00085)$ & $(0,00085)$ \\
\hline \multirow[t]{2}{*}{ Unemployment dummy } & $0,03959 * * *$ & $0,04131^{* * *}$ & $0,03977^{* * *}$ & $0,03595^{* * *}$ & $0,03652^{* * *}$ & 0,00976 & 0,00920 & 0,00904 & 0,00647 & 0,00633 \\
\hline & $(0,00552)$ & $(0,00568)$ & $(0,00553)$ & $(0,00518)$ & $(0,00524)$ & $(0,00799)$ & $(0,00776)$ & $(0,00765)$ & $(0,00679)$ & $(0,00676)$ \\
\hline \multirow[t]{2}{*}{ Age } & & $0,00064^{* * *}$ & $0,00064^{* * *}$ & $0,00133^{* * *}$ & $0,00170 * * *$ & & $0,00067 * * *$ & $0,00067^{* * *}$ & $0,00133^{* * *}$ & $0,00165^{* * *}$ \\
\hline & & $(0,00019)$ & $(0,00019)$ & $(0,00019)$ & $(0,00019)$ & & $(0,00019)$ & $(0,00018)$ & $(0,00019)$ & $(0,00019)$ \\
\hline \multirow[t]{2}{*}{ Age2 } & & $-0,00001^{* * *}$ & $-0,00001^{* * *}$ & $-0,00001^{* * *}$ & $-0,00002^{* * *}$ & & $-0,00000^{* * *}$ & $-0,00001^{* * *}$ & $-0,00001^{* * *}$ & $-0,00002^{* * *}$ \\
\hline & & $(0,00000)$ & $(0,00000)$ & $(0,00000)$ & $(0,00000)$ & & $(0,00000)$ & $(0,00000)$ & $(0,00000)$ & $(0,00000)$ \\
\hline \multirow[t]{2}{*}{ Education: Degree } & & & $-0,00699^{* * *}$ & $-0,00689^{* * *}$ & $-0,00704^{* * *}$ & & & $-0,00636^{* * *}$ & $-0,00639^{* * *}$ & $-0,00649^{* * *}$ \\
\hline & & & $(0,00045)$ & $(0,00044)$ & $(0,00044)$ & & & $(0,00047)$ & $(0,00045)$ & $(0,00045)$ \\
\hline \multirow[t]{2}{*}{ Education: Higher } & & & $-0,00354^{* * *}$ & $-0,00309^{* * *}$ & $-0,00307^{* * *}$ & & & $-0,00310^{* * *}$ & $-0,00279^{* * *}$ & $-0,00276^{* * *}$ \\
\hline & & & $(0,00050)$ & $(0,00050)$ & $(0,00050)$ & & & $(0,00050)$ & $(0,00049)$ & $(0,00049)$ \\
\hline \multirow[t]{2}{*}{ Education: Alevel } & & & $-0,00296^{* * *}$ & $-0,00249^{* * *}$ & $-0,00249^{* * *}$ & & & $-0,00264^{* * *}$ & $-0,00230^{* * *}$ & $-0,00229^{* * *}$ \\
\hline & & & $(0,00048)$ & $(0,00047)$ & $(0,00047)$ & & & $(0,00050)$ & $(0,00049)$ & $(0,00049)$ \\
\hline \multirow[t]{2}{*}{ Education: Olevel } & & & $-0,00404^{* * *}$ & $-0,00349^{* * *}$ & $-0,00344^{* * *}$ & & & $-0,00390^{* * *}$ & $-0,00348^{* * *}$ & $-0,00344^{* * *}$ \\
\hline & & & $(0,00047)$ & $(0,00047)$ & $(0,00047)$ & & & $(0,00047)$ & $(0,00046)$ & $(0,00046)$ \\
\hline \multirow[t]{2}{*}{ Education: Other } & & & $-0,00171^{* * *}$ & $-0,00122^{* *}$ & $-0,00123^{* *}$ & & & $-0,00151^{* * *}$ & $-0,00115^{* *}$ & $-0,00115^{* *}$ \\
\hline & & & $(0,00055)$ & $(0,00055)$ & $(0,00055)$ & & & $(0,00058)$ & $(0,00058)$ & $(0,00058)$ \\
\hline \multirow[t]{2}{*}{ Married } & & & & $-0,00981^{* * *}$ & $-0,00888^{* * *}$ & & & & $-0,00895^{* * *}$ & $-0,00817^{* * *}$ \\
\hline & & & & $(0,00045)$ & $(0,00048)$ & & & & $(0,00046)$ & $(0,00049)$ \\
\hline \multirow[t]{2}{*}{ Children dummy } & & & & & $-0,00233^{* * *}$ & & & & & $-0,00189^{* * *}$ \\
\hline & & & & & $(0,00030)$ & & & & & $(0,00030)$ \\
\hline $\mathrm{N}$ & & & 632,129 & & & & & 612,116 & & \\
\hline
\end{tabular}

Note: ${ }^{* *} \mathrm{p}<0.01,{ }^{* *} \mathrm{p}<0.05,{ }^{*} \mathrm{p}<0.1$. The regression equations are estimated as probit models with standard errors clustered at region, year and quarter level. 
Table 3. Marginal Effects

\begin{tabular}{|c|c|c|c|c|}
\hline & \multicolumn{2}{|c|}{ Male } & \multicolumn{2}{|c|}{ Female } \\
\hline & Married & Single & Married & Single \\
\hline \multirow{6}{*}{$\begin{array}{l}\text { Reg. unemployment rate } \\
\text { (Employed) } \\
\text { Reg. unemployment rate } \\
\text { (Unemployed) } \\
\text { Unemployment dummy }\end{array}$} & $0,00039^{* *}$ & 0,00015 & 0,00042 & $0,00104^{*}$ \\
\hline & $(0,00016)$ & $(0,00026)$ & $(0,00029)$ & $(0,00062)$ \\
\hline & 0,00030 & $-0,00085^{*}$ & $0,00227^{* *}$ & 0,00095 \\
\hline & $(0,00043)$ & $(0,00045)$ & $(0,00115)$ & $(0,00155)$ \\
\hline & $0,01302^{*}$ & $0,04308^{* * *}$ & $-0,00265$ & 0,02410 \\
\hline & $(0,00740)$ & $(0,01387)$ & $(0,00526)$ & $(0,01845)$ \\
\hline \multirow[t]{2}{*}{ Age } & 0,00034 & $0,00183^{* * *}$ & $0,00072^{* * *}$ & $0,00234^{* * *}$ \\
\hline & $(0,00024)$ & $(0,00028)$ & $(0,00023)$ & $(0,00034)$ \\
\hline \multirow[t]{2}{*}{ Age2 } & $-0,00000$ & $-0,00002^{* * *}$ & $-0,00001^{* *}$ & $-0,00002^{* * *}$ \\
\hline & $(0,00000)$ & $(0,00000)$ & $(0,00000)$ & $(0,00000)$ \\
\hline \multirow[t]{2}{*}{ Education: Degree } & $-0,00307^{* * *}$ & $-0,00364^{* * *}$ & $-0,00571^{* * *}$ & $-0,01003^{* * *}$ \\
\hline & $(0,00046)$ & $(0,00081)$ & $(0,00052)$ & $(0,00098)$ \\
\hline \multirow[t]{2}{*}{ Education: Higher } & $-0,00222^{* * *}$ & $-0,00214^{* *}$ & $-0,00170^{* * *}$ & $-0,00624^{* * *}$ \\
\hline & $(0,00051)$ & $(0,00088)$ & $(0,00056)$ & $(0,00101)$ \\
\hline \multirow[t]{2}{*}{ Education: Alevel } & $-0,00333^{* * *}$ & $-0,00337^{* * *}$ & $-0,00156^{* *}$ & $-0,00495^{* * *}$ \\
\hline & $(0,00044)$ & $(0,00074)$ & $(0,00061)$ & $(0,00099)$ \\
\hline \multirow[t]{2}{*}{ Education: Olevel } & $-0,00097^{* *}$ & $-0,00104$ & $-0,00265^{* * *}$ & $-0,00612^{* * *}$ \\
\hline & $(0,00050)$ & $(0,00083)$ & $(0,00056)$ & $(0,00102)$ \\
\hline \multirow[t]{2}{*}{ Education: Other } & $-0,00072$ & $-0,00168$ & 0,00021 & $-0,00548^{* * *}$ \\
\hline & $(0,00051)$ & $(0,00103)$ & $(0,00071)$ & $(0,00116)$ \\
\hline \multirow[t]{2}{*}{ Children dummy } & $-0,00019$ & $-0,00358^{* * *}$ & $-0,00135^{* * *}$ & $-0,00363^{* * *}$ \\
\hline & $(0,00030)$ & $(0,00056)$ & $(0,00035)$ & $(0,00064)$ \\
\hline $\mathrm{N}$ & 348,859 & 182,274 & 438,304 & 173,812 \\
\hline
\end{tabular}

Table 3 reports the results by marital status. Mental health of employed women differ depending on whether they are married or not. ${ }^{18}$ When economic situation worsen single women are more than twice as likely to suffer depression than married women (0.104 pp vs. $0.042 \mathrm{pp}$ ). Married people have more economic resources than unmarried ones (Ross et al., 1990; Zick \& Smith, 1991), and the economic benefits of marriage primarily derive from the dual-earning potential for the married and these benefits exists for men as well as women (Ross et al., 1990). Note that the probability of mental problems in married employed men rise by almost the same amount $(0.039 \mathrm{pp})$ as in married employed women (0.041 pp) for the percentage point rise in the regional unemployment rate. Hence, we observe higher probability of depression for single employed women as a downturn of the labor market raises their job insecurity to a greater extent since in the case of unemployment they will face more financial strain than married women. Unemployed married women have the highest probability of suffering depression in response to a rise in the regional unemployment rate. It should be first noted that women have generally been shown to respond to stressful life events (such as unemployment) with higher levels of depression and anxiety (Eliason \& Storrie, 2009) compared to men. Furthermore, Cochrane (1981) finds that whether or not a married woman is employed is a major predictor of depression symptoms. Hence, unemployed married women are affected more by economic downturns than employed, married or single women. Compared to unemployed married men, they

\footnotetext{
${ }^{18}$ Although our analysis cannot reveal the mechanism behind the effect of marriage among women and men, as we do not have information about spouse's employment status. LFS is not a household survey and we can disclose the information about spouses of less than $50 \%$ of married individuals, which is rather a selected sample. The Appendix contains summary statistics for both sub-samples.
} 
also have a higher probability of anxiety and depression in bad times. Rosenfield (1989) uses power explanation for this difference that predicts that employment for women is associated with greater power in the family, thus married women might have higher rates of anxious and depression symptoms than married men when they become unemployed, since unemployment would reduce this power and the bad economic situation would lower her chances to find employment. An alternative explanation would involve the fact that unemployed married women worry more about the economic situation compared to the employed. If a woman is unemployed, her spouse, if employed, is the sole family wage earner. During an economic downturn, not only do her chances to be reemployed decrease, but also her spouse's probability to lose a job rises (or should he already be unemployed, his chances of finding a job). Thus, she might feel more depressed than if she is employed.

Compared to single men, a more pronounced effect of macroeconomic conditions on the mental health of married men may then be explained by being married entails additional stress due to greater financial responsibilities and the role as the primary provider for the family. We do not observe much difference between the probability of depression as a response to changes in the unemployment rate for employed and unemployed married men, except that it is not significant for the unemployed . The effect of regional unemployment is opposite for unemployed single men: they benefit from living in high unemployment regions in bad times. This finding is consistent with a 'social norm' effect of unemployment in mental well-being literature (Jackson and Warr, 1987; Clark, 2003; Shields and Wheatley Price, 2005). Similar results have been found for Germany (Clark et al. 2009), Australia (Shields et al., 2009), and Switzerland (Stutzer and Lalive, 2004). Kessler et al. (1988) highlight the importance of psychological and social support from others to attenuate the negative impact of own unemployment on mental health. It might be easier for unemployed men to find such support when the others in the local area are also unemployed, which helps them to resist depression and anxiety. Jackson and Warr (1987) note that long term high local unemployment may give rise to stronger social support networks, greater material help, and institutional changes, which protect jobless people to some extent. However, it seems that it is not the case for the unemployed married men, perhaps due to the overlap with family responsibilities.

\section{Robustness checks}

\subsection{Unemployment due to Redundancy}

We perform a series of check in order to check whether the results are robust. The first one concerns whether we have corrected well for endogeneity of own employment status. The LFS survey is quarterly and the individuals are asked in every quarter when they became unemployed. If they became unemployed due to redundancy in the last three months, they are additionally asked whether or not it was due to plant closure. Note that plant closure is a particular case of redundancy, widely used in the literature (Sullivan and von Wachter, 2009; Eliason and Storrie, 2009; Salm, 2009; Browning,et al. 2006). Mass layoffs are frequently used in the literature since they are considered as not related to individual's health outcomes as reasons of unemployment (Schmitz, 2011; Khun et al., 2009). Hence it is of interest to see whether the results obtained for all redundant workers (in this case those being made redundant in the last three months, since we have information only 
about plant closure redundancies in the last three months) are in line with the results for the plant closure subsample. Specification (1) includes all the unemployed individuals who became unemployed in the last three months, specification (2) includes those who became unemployed due to redundancy in the last three months, and specification (3) those who lost their job as a result of firm or plant closure in the last three months. Table 4 summarize the results:

Table 4. Robustness checks: Firm closure

\begin{tabular}{|c|c|c|c|c|c|c|}
\hline & \multicolumn{3}{|c|}{ Male } & \multicolumn{3}{|c|}{ Female } \\
\hline & (1) & $(2)$ & $(3)$ & (1) & $(2)$ & $(3)$ \\
\hline \multirow{6}{*}{$\begin{array}{l}\text { Reg. unemployment rate } \\
\text { (Employed) } \\
\text { Reg. unemployment rate } \\
\text { (Unemployed) } \\
\text { Unemployment dummy }\end{array}$} & $0,00028^{* *}$ & $0,00030^{* *}$ & $0,00030^{* *}$ & $0,00050^{*}$ & $0,00052^{*}$ & $0,00052^{*}$ \\
\hline & $(0,00014)$ & $(0,00014)$ & $(0,00014)$ & $(0,00029)$ & $(0,00029)$ & $(0,00029)$ \\
\hline & $-0,00102^{* *}$ & $-0,00031$ & $-0,00042$ & $-0,00049$ & 0,00213 & 0,00683 \\
\hline & $(0,00046)$ & $(0,00065)$ & $(0,00182)$ & $(0,00110)$ & $(0,00219)$ & $(0,00449)$ \\
\hline & $0,03069^{* * *}$ & 0,00888 & 0,00883 & $0,02251^{*}$ & $-0,00578$ & $-0,01200$ \\
\hline & $(0,01123)$ & $(0,00849)$ & $(0,02312)$ & $(0,01365)$ & $(0,00703)$ & $(0,00875)$ \\
\hline \multirow[t]{2}{*}{ Age } & $0,00118^{* * *}$ & $0,00118^{* * *}$ & $0,00119^{* * *}$ & $0,00169^{* * *}$ & $0,00165^{* * *}$ & $0,00167 * * *$ \\
\hline & $(0,00015)$ & $(0,00016)$ & $(0,00015)$ & $(0,00019)$ & $(0,00019)$ & $(0,00019)$ \\
\hline \multirow[t]{2}{*}{ Age2 } & $-0,00001^{* * *}$ & $-0,00001^{* * *}$ & $-0,00001^{* * *}$ & $-0,00002^{* * *}$ & $-0,00002^{* * *}$ & $-0,00002^{* * *}$ \\
\hline & $(0,00000)$ & $(0,00000)$ & $(0,00000)$ & $(0,00000)$ & $(0,00000)$ & $(0,00000)$ \\
\hline \multirow[t]{2}{*}{ Education: Degree } & $-0,00320^{* * *}$ & $-0,00319^{* * *}$ & $-0,00314^{* * *}$ & $-0,00642^{* * *}$ & $-0,00641^{* * *}$ & $-0,00639^{* * *}$ \\
\hline & $(0,00042)$ & $(0,00042)$ & $(0,00042)$ & $(0,00045)$ & $(0,00046)$ & $(0,00046)$ \\
\hline \multirow[t]{2}{*}{ Education: Higher } & $-0,00221^{* * *}$ & $-0,00219^{* * *}$ & $-0,00215^{* * *}$ & $-0,00274^{* * *}$ & $-0,00272^{* * *}$ & $-0,00270^{* * *}$ \\
\hline & $(0,00044)$ & $(0,00043)$ & $(0,00044)$ & $(0,00050)$ & $(0,00050)$ & $(0,00050)$ \\
\hline \multirow[t]{2}{*}{ Education: Alevel } & $-0,00328^{* * *}$ & $-0,00327^{* * *}$ & $-0,00321^{* * *}$ & $-0,00226^{* * *}$ & $-0,00225^{* * *}$ & $-0,00223^{* * *}$ \\
\hline & $(0,00042)$ & $(0,00042)$ & $(0,00042)$ & $(0,00049)$ & $(0,00049)$ & $(0,00049)$ \\
\hline \multirow[t]{2}{*}{ Education: Olevel } & $-0,00107^{* *}$ & $-0,00107^{* *}$ & $-0,00101^{* *}$ & $-0,00341^{* * *}$ & $-0,00340^{* * *}$ & $-0,00337^{* * *}$ \\
\hline & $(0,00047)$ & $(0,00047)$ & $(0,00047)$ & $(0,00047)$ & $(0,00047)$ & $(0,00048)$ \\
\hline \multirow[t]{2}{*}{ Education: Other } & $-0,00099^{*}$ & $-0,00100^{*}$ & $-0,00097^{*}$ & $-0,00098^{*}$ & $-0,00101^{*}$ & $-0,00101^{*}$ \\
\hline & $(0,00051)$ & $(0,00051)$ & $(0,00051)$ & $(0,00058)$ & $(0,00058)$ & $(0,00058)$ \\
\hline \multirow[t]{2}{*}{ Married } & $-0,00533^{* * *}$ & $-0,00535^{* * *}$ & $-0,00532^{* * *}$ & $-0,00809^{* * *}$ & $-0,00805^{* * *}$ & $-0,00805^{* * *}$ \\
\hline & $(0,00034)$ & $(0,00034)$ & $(0,00033)$ & $(0,00049)$ & $(0,00049)$ & $(0,00049)$ \\
\hline \multirow[t]{2}{*}{ Children dummy } & $-0,00116^{* * *}$ & $-0,00114^{* * *}$ & $-0,00115^{* * *}$ & $-0,00194^{* * *}$ & $-0,00190^{* * *}$ & $-0,00192^{* * *}$ \\
\hline & $(0,00028)$ & $(0,00028)$ & $(0,00028)$ & $(0,00030)$ & $(0,00030)$ & $(0,00030)$ \\
\hline $\mathrm{N}$ & 528,433 & 525,264 & 523,769 & 612,270 & 609,469 & 608,777 \\
\hline
\end{tabular}

Notes: ${ }^{* * *} \mathrm{p}<0.01,{ }^{* *} \mathrm{p}<0.05,{ }^{*} \mathrm{p}<0.1$.

(1) All Unemployed, (2) Unemployed due Redundancy, (3) Unemployed due firm closure

It is worth noting that the results for the employed do not vary greatly in all specifications and are similar to those from Tables 2.1. and 2.2. Hence, we confirm that economic downturns are associated with a higher probability of mental problems for the employed. For the unemployed men, the direction of the results is also similar to those in Table 2.1. The magnitudes in specifications (2) and (3) are similar and the effect of the increase in the regional unemployment rate is negative, suggesting that unemployed men are at lower risk of depression compared to employed men. The coefficient of being unemployed is much smaller and not significant compared to specification (1) which provides few important conclusions. First, without controlling for endogeneity, the result seems to go from mental health to unemployment: depressed people are more likely to become unemployed, this finding is in line with Hamilton et al. (1997) that documents the beneficial effects of mental health on employability. Second, the effect is smaller compared to results from Table 2.1., the only difference was in the duration of unemployment. We thus confirm that 
short unemployment does not lead to mental problems, compared to longer unemployment spells, which is in line with Bjorklund and Eriksson (1998) for mental health, and Classen and Dunn (2012) who found that unemployment duration is the dominant force in the relationship between job loss and suicide. For unemployed women, while the coefficients are not significant and different in magnitudes, we confirm that they are at higher risk of depression when the economic situation worsens, however signs of unemployment dummies are negative.

\subsection{Mobility}

One important issue that we have not discussed so far is the possibility of migration from high-unemployment regions to low unemployment regions. People without mental problems could be more flexible about moving to another region with better employment conditions ${ }^{19}$ More people with mental problems may be observed in regions with high unemployment just because they are more likely to stay in these regions, while people without such problems could move more easily to regions with lower unemployment. One possibility is to exclude individuals who have recently arrived to the region. ${ }^{20}$ According to the ONS (and United Nations definition for population estimates), the usually resident population of an area includes people who have resided in this area for a period of at least 12 months. Thus, we restrict the sample to those who live at the same address for at least 12 months. ${ }^{21}$ Specification "All" includes all individuals and specification "More than 1 $\mathrm{yr}^{\prime \prime}$ only those who have lived in a region for at least 12 months. The idea is to ensure that the results will not change greatly if we exclude those who have recently moved, the probability of suffering mental problems if the individual lives in the high unemployment region would be smaller than if we analyzed the whole sample, since by deleting migrants we increase the proportion of mentally ill people in the regions with low unemployment rate. The results are presented in Table 5.

\footnotetext{
${ }^{19}$ In Ruhm $(2000,2005)$, he notes that migrants tend to be young and healthy and usually relocate into areas with robust economies, which in the case of mortality rates may induce a spurious negative correlation between economic conditions and mortality rates, and in the case of healthy lifestyles militate against the finding that lifestyles become healthier when economic conditions deteriorate.

${ }^{20}$ Another possibility is to assess the information on the region of birth, and analyze the sample of those working and living in their region of birth. However, LFS does not provide such information.

${ }^{21}$ In principle LFS can discriminate whether an individual resides at the same address for less than 12 months, between 12 months and 2 years, between 2 and 3 years, between 3 and 5 years, between 5 and 10 years, and over 10 years. However, this information relates to address rather than place. It may be possible that an individual is living at a different address from 12 months ago but is living in the same town and county. Hence, we do not have precise information regarding for how long an individual has resided in the region.
} 
Table 5. Robustness checks: Length of residence

\begin{tabular}{|c|c|c|c|c|}
\hline & \multicolumn{2}{|c|}{ Male } & \multicolumn{2}{|c|}{ Female } \\
\hline & All & More then $1 \mathrm{yr}$ & All & More then 1 yr \\
\hline \multirow{6}{*}{$\begin{array}{l}\text { Reg. unemployment rate } \\
\text { (Employed) } \\
\text { Reg. unemployment rate } \\
\text { (Unemployed) } \\
\text { Unemployment dummy }\end{array}$} & $0,00031^{* *}$ & $0,00036^{* *}$ & $0,00057^{*}$ & $0,00063^{* *}$ \\
\hline & $(0,00014)$ & $(0,00014)$ & $(0,00030)$ & $(0,00031)$ \\
\hline & $-0,00021$ & $-0,00026$ & $0,00150^{*}$ & 0,00141 \\
\hline & $(0,00031)$ & $(0,00033)$ & $(0,00085)$ & $(0,00091)$ \\
\hline & $0,02583^{* * *}$ & $0,02810^{* * *}$ & 0,00633 & 0,00837 \\
\hline & $(0,00811)$ & $(0,00885)$ & $(0,00676)$ & $(0,00802)$ \\
\hline \multirow[t]{2}{*}{ Age } & $0,00115^{* * *}$ & $0,00135^{* * *}$ & $0,00165^{* * *}$ & $0,00143^{* * *}$ \\
\hline & $(0,00016)$ & $(0,00018)$ & $(0,00019)$ & $(0,00020)$ \\
\hline \multirow[t]{2}{*}{ Age2 } & $-0,00001^{* * *}$ & $-0,00001^{* * *}$ & $-0,00002^{* * *}$ & $-0,00001^{* * *}$ \\
\hline & $(0,00000)$ & $(0,00000)$ & $(0,00000)$ & $(0,00000)$ \\
\hline \multirow[t]{2}{*}{ Education: Degree } & $-0,00327^{* * *}$ & $-0,00317^{* * *}$ & $-0,00649^{* * *}$ & $-0,00644^{* * *}$ \\
\hline & $(0,00042)$ & $(0,00045)$ & $(0,00045)$ & $(0,00047)$ \\
\hline \multirow[t]{2}{*}{ Education: Higher } & $-0,00223^{* * *}$ & $-0,00230^{* * *}$ & $-0,00276^{* * *}$ & $-0,00294^{* * *}$ \\
\hline & $(0,00043)$ & $(0,00047)$ & $(0,00049)$ & $(0,00050)$ \\
\hline \multirow[t]{2}{*}{ Education: Alevel } & $-0,00339^{* * *}$ & $-0,00349^{* * *}$ & $-0,00229^{* * *}$ & $-0,00230^{* * *}$ \\
\hline & $(0,00041)$ & $(0,00045)$ & $(0,00049)$ & $(0,00050)$ \\
\hline \multirow[t]{2}{*}{ Education: Olevel } & $-0,00104^{* *}$ & $-0,00090^{*}$ & $-0,00344^{* * *}$ & $-0,00347^{* * *}$ \\
\hline & $(0,00048)$ & $(0,00051)$ & $(0,00046)$ & $(0,00049)$ \\
\hline \multirow[t]{2}{*}{ Education: Other } & $-0,00104^{* *}$ & $-0,00078$ & $-0,00115^{* *}$ & $-0,00099$ \\
\hline & $(0,00051)$ & $(0,00056)$ & $(0,00058)$ & $(0,00061)$ \\
\hline \multirow[t]{2}{*}{ Married } & $-0,00545^{* * *}$ & $-0,00539^{* * *}$ & $-0,00817^{* * *}$ & $-0,00869^{* * *}$ \\
\hline & $(0,00034)$ & $(0,00038)$ & $(0,00049)$ & $(0,00053)$ \\
\hline \multirow[t]{2}{*}{ Children dummy } & $-0,00109^{* * *}$ & $-0,00134^{* * *}$ & $-0,00189^{* * *}$ & $-0,00208^{* * *}$ \\
\hline & $(0,00028)$ & $(0,00029)$ & $(0,00030)$ & $(0,00033)$ \\
\hline $\mathrm{N}$ & 531,133 & 471,342 & 612,116 & 558,999 \\
\hline
\end{tabular}

The results for those living in the region longer than a year are not smaller than those for the sample including individuals who have recently moved, in fact they are slightly bigger. Thus migration of people without mental problems to regions with low unemployment does not seem to be a problem of our study.

\subsection{Lags}

Following Ruhm (2000, 2003, 2005), we wanted to check whether economic conditions have the non-contemporaneous effect on mental problems. As he noted, it may seem surprising that using unemployment rates during only a three-month period we are able to find effects for depression and anxiety which probably respond slowly to changes in macroeconomic conditions. But since unemployment rates correlate over time, our results reflect the effects of economic conditions over a longer than just a quarter period. In particular, we tried to look at what would happen if we moved the unemployment window: we estimate the model taking the unemployment rate from a quarter before (3-m un.rate) the survey date, and the 12-months average (12-m un.rate) before the survey date. Table 6 summarize the results for these specifications. 
Table 6. Lags

\begin{tabular}{|c|c|c|c|c|}
\hline & \multicolumn{2}{|c|}{ Male } & \multicolumn{2}{|c|}{ Female } \\
\hline & 3-m un.rate & 12-m un.rate & 3-m un.rate & 12-m un.rate \\
\hline \multirow{6}{*}{$\begin{array}{l}\text { Reg. unemployment rate } \\
\text { (Employed) } \\
\text { Reg. unemployment rate } \\
\text { (Unemployed) } \\
\text { Unemployment dummy }\end{array}$} & $0,00031^{* *}$ & $0,00045^{* * *}$ & $0,00057^{*}$ & $0,00054^{*}$ \\
\hline & $(0,00014)$ & $(0,00014)$ & $(0,00030)$ & $(0,00032)$ \\
\hline & $-0,00021$ & 0,00007 & $0,00150^{*}$ & $0,00192^{* *}$ \\
\hline & $(0,00031)$ & $(0,00032)$ & $(0,00085)$ & $(0,00091)$ \\
\hline & $0,02583^{* * *}$ & $0,02269 * * *$ & 0,00633 & 0,00307 \\
\hline & $(0,00811)$ & $(0,00737)$ & $(0,00676)$ & $(0,00596)$ \\
\hline \multirow[t]{2}{*}{ Age } & $0,00115^{* * *}$ & $0,00115^{* * *}$ & $0,00165^{* * *}$ & $0,00165^{* * *}$ \\
\hline & $(0,00016)$ & $(0,00016)$ & $(0,00019)$ & $(0,00019)$ \\
\hline \multirow[t]{2}{*}{ Age2 } & $-0,00001^{* * *}$ & $-0,00001^{* * *}$ & $-0,00002^{* * *}$ & $-0,00002^{* * *}$ \\
\hline & $(0,00000)$ & $(0,00000)$ & $(0,00000)$ & $(0,00000)$ \\
\hline \multirow[t]{2}{*}{ Education: Degree } & $-0,00327^{* * *}$ & $-0,00327^{* * *}$ & $-0,00649^{* * *}$ & $-0,00649^{* * *}$ \\
\hline & $(0,00042)$ & $(0,00042)$ & $(0,00045)$ & $(0,00045)$ \\
\hline \multirow[t]{2}{*}{ Education: Higher } & $-0,00223^{* * *}$ & $-0,00224^{* * *}$ & $-0,00276^{* * *}$ & $-0,00276^{* * *}$ \\
\hline & $(0,00043)$ & $(0,00043)$ & $(0,00049)$ & $(0,00049)$ \\
\hline \multirow[t]{2}{*}{ Education: Alevel } & $-0,00339^{* * *}$ & $-0,00339^{* * *}$ & $-0,00229^{* * *}$ & $-0,00229^{* * *}$ \\
\hline & $(0,00041)$ & $(0,00041)$ & $(0,00049)$ & $(0,00049)$ \\
\hline \multirow[t]{2}{*}{ Education: Olevel } & $-0,00104^{* *}$ & $-0,00104^{* *}$ & $-0,00344^{* * *}$ & $-0,00344^{* * *}$ \\
\hline & $(0,00048)$ & $(0,00048)$ & $(0,00046)$ & $(0,00047)$ \\
\hline \multirow[t]{2}{*}{ Education: Other } & $-0,00104^{* *}$ & $-0,00104^{* *}$ & $-0,00115^{* *}$ & $-0,00115^{* *}$ \\
\hline & $(0,00051)$ & $(0,00051)$ & $(0,00058)$ & $(0,00058)$ \\
\hline \multirow[t]{2}{*}{ Married } & $-0,00545^{* * *}$ & $-0,00545^{* * *}$ & $-0,00817^{* * *}$ & $-0,00817^{* * *}$ \\
\hline & $(0,00034)$ & $(0,00034)$ & $(0,00049)$ & $(0,00049)$ \\
\hline \multirow[t]{2}{*}{ Children dummy } & $-0,00109^{* * *}$ & $-0,00110^{* * *}$ & $-0,00189^{* * *}$ & $-0,00189^{* * *}$ \\
\hline & $(0,00028)$ & $(0,00028)$ & $(0,00030)$ & $(0,00030)$ \\
\hline $\mathrm{N}$ & 531,133 & 531,133 & 612,116 & 612,116 \\
\hline
\end{tabular}

The findings suggest that the macroeconomic effects accumulate over time for employed men and unemployed women: higher unemployment during previous year predicts a statistically significant rise in mental problems. For the employed women, the effect for one quarter unemployment rate is very similar to a 1-year average, while is slightly smaller. Unemployed men are at lower risk of depression compared to employed men in both specifications, while if we consider a 1-year average, the sign is not negative. Together these findings show that mental health problems associated with economic downturns occur with a delay for some subgroups, which should be carefully considered when suggesting health policies promoting mental health.

\section{Conclusion}

The deterioration of labor market conditions during the 2007 recession has led many to refer to the downturn as the Great Recession (Elsby, 2010). High unemployment rates are likely to create negative externalities. Employed people start to feel less secure about being able to keep their job, while the unemployed have fewer possibilities of finding a new one. All these experiences are likely to have a negative impact on mental health: when labour market prospects worsen, people are more likely to suffer a mental problem such an anxiety or depression. These findings are important since the productivity of workers might be affected by mental problems in recessions which arise from job insecurity, and other stress induced by cuts in pay or hours. Another reason to care about the effect of 
economics on mental health is that health care costs associated with mental diseases have substantially risen in the last decades in most industrialized countries and in particularly in the UK (McVicar and Anyadike-Danes, 2008), while the dynamics of these costs may be related to economic conditions. However, apart from these negative effects, there may be some positive impact on the subgroups of the unemployed: social pressure for not following the norm decreases when more people deviate from the norm, in this case become unemployed. Thus some unemployed might be at lower risk of mental problems.

This study sought to assess how economic fluctuations, through changes in the regional unemployment rate, affect the mental health of individuals who are active on the labor market. We use the UK's Labour Force Survey from 1997 to 2010 in order to clarify whether increases in the regional unemployment rate affect mental problems. Since the unemployment rate influences people differently depending on their employment status we control for it. We show that it is important to correct for endogeneity of the former, otherwise the results are biased.

The obtained results suggest that, when the economy deteriorates, married employed men, married employed and unemployed women are more likely to suffer depression or anxiety. Employed married men may have depressive thought about their working prospects in the light of higher unemployment and worry that they will be unable to provide sufficient financial support for their families. Moreover, jobs are related to social status and self-assertion, and they therefore could be depressed due to fear of losing these social identifications. In the case of women, the results are more complex. Employed married women are as likely to suffer depression in recession as employed married men, while employed single women are at higher risk. This difference could be attributed to greater economic resources associated with marriage. However, the unemployed married women are even at higher risk of mental problems in recessions than single ones, which might be related to power in the family related to employment, that married women lose once they became unemployed. The interesting part is that single unemployed men are at lower risk of mental problems compared to all above groups. Several factors could be responsible for this. The first is that social pressure on the unemployed in bad times is much lower, than when there are just a few unemployed people. Society seems to be more tolerant and compassionate with respect to unemployed single men when unemployment is widespread. And second, other unemployed people could provide emotional support, which in the case of mental problems such as anxiety is of great importance. Several robustness checks confirm our findings.

Some limitations of the research regarding data unavailability exist. First, the probability of becoming unemployed is different depending on the educational level of the individual (Nickell, 1979) and we would thus rather define the regional gender-specific unemployment rate at educational level as well. Unfortunately, the ONS does not provide information about regional unemployment rates by educational attainment. Second, information is needed about the spouse's employment status to reveal the mechanism behind the differential effect of economic conditions on mental problems among men and women. Since LFS is not a household survey, it does not provide information about spouses. Future research should take these limitations into consideration and use longitudinal data to account for possible individual unobservable effects.

Our results are in line with previous research (in particular Ruhm, 2003; Clark, 2003, 2009, 2010; Tefft, 2011a, 2011b), while we provide wider evidence related to subgroups. 
This is important to bear in mind when designing labour and health policies, as they could be more efficient if target groups are correctly specified.

\section{References}

[1] Aneshensel C.S., Phelan J.C. (1999). Handbook of the sociology of mental health. p. 237

[2] Bara, A., Arber, S. (2009). Working shifts and mental health - findings from the British Household Panel Survey (1995-2005). Scandinavian Journal of Work Environment \& Health, 35 (5) p. 361 - 367

[3] Brenner, M.H., (1973). Mental Illness and the Economy. Harvard University Press, Cambridge.

[4] Browning M., Moller Dano A., Heinesen E. (2006). Job displacement and stressrelated health outcomes. Health Economics, 15. p. 1061-1075

[5] Better Or Worse: A Longitudinal Study Of The Mental Health Of Adults In Great Britain, National Statistics, 2003

[6] Björklund A. (1985). Unemployment and mental health: some evidence from panel data. The Journal of Human Resources, 20. p.469-483.

[7] Björklund A., Eriksson T. (1998). Unemployment and mental health: Evidence from research in Nordic countries. Scandinavian Journal of Social Welfare, 7. p. 219-235.

[8] British Psycological Society. (2011). Mental health problems can affect employment opportunities, April 5.

[9] Clark A., Knabe A., Rätzel S. (2010). Boon or bane? Others' unemployment, wellbeing and job insecurity. Labour Economics, 17(1). p. 52-61.

[10] Clark A., Knabe A., Rätzel S. (2009). Unemployment as a Social Norm in Germany. Journal of Applied Social Science Studies, 129(2). p. 251-260.

[11] Clark, A.E. (2003). Unemployment as a Social Norm: Psychological Evidence from Panel Data. Journal of Labor Economics, 21 (2), p. 323-351.

[12] Clark, A.E., Oswald A. (1994). Unhappiness and Unemployment. Economic Journal, 104, p. 648-659.

[13] Classen T.J., Dunn R.A. (2012). The effect of job loss and unemployment duration on suicide risk in the United States: a new look using mass-layoffs and unemployment duration. Health Economics, 21 (3), p. 338-350.

[14] Cohn R. (1978). The effect of employment status change on self-attitudes. Social Psychology 41. p. 81-93. 
[15] Di Tella, R., MacCulloch R., Oswald A. (2001). Preferences over Inflation and Unemployment: Evidence from Surveys of Happiness. American Economic Review, 91. p. 335-341.

[16] Eisenberg P., Lazarsfeld P. (1938). The psychological effects of unemployment. Psychological Bulletin, 35. p. 358-390.

[17] Eliason M., Storrie D. (2009). Job loss is bad for your health - Swedish evidence on cause-specific hospitalization following involuntary job loss. Social Science \& Medicine, 68(8), p. 1396-1406

[18] Elsby M., Hobijn B., Sahin A. (2010). The Labor Market in the Great Recession. Material from Conference "Brookings Panel on Economic Activity", March 18-19, AEA.

[19] Jackson P., Warr P. (1987). Mental health of unemployed men in different parts of England and Wales. British Medical Journal, 295 p. 525.

[20] Hamilton,V.H., Merrigan, P., Dufresne, E. (1997). Down and out: estimating the relationship between mental health and unemployment. Health Economics, 6(4). p.397406.

[21] Hartley J., Jacobson D., Klandermans B., van Vuuren. T., Greenhalgh L., Sutton R. (1991). Job Insecurity: Coping with jobs at risk, London.

[22] Horwitz, A. V., White, H. R., Howell-White S. (1996). Becoming Married and Mental Health: A Longitudinal Study of a Cohort of Young Adults. Journal of Marriage and Family, 58(4). p. 895-907

[23] Horwitz, A. V., White, H. R. (1991). Marital status, depression, and alcohol problems among young adults. Journal of Health and Social Behavior, 32. p.221-237.

[24] Kessler R.. Turner J., House J., (1988). The effects of unemployment on health in a community survey: main, modifying, and mediating effects. Journal of Social Issues, 44. p. $69-85$.

[25] Kuhn A., Lalive R., Zweimuller J. (2009). The Public Health Costs of Unemployment. Journal of Health Economics, 28(6), p. 1099-1115.

[26] McVicar D, Anyadike-Danes M. (2008). Panel estimates of the determinants of British regional male incapacity benefits rolls 1998-2006. Applied Economics, 40, p. 1-15.

[27] Moniruzzamana S., Andersson R. (2004). Relationship between economic development and suicide mortality: a global cross-sectional analysis in an epidemiological transition perspective. Public Health, 118, p. 346-348.

[28] Morris J.K., Cook D.G. (1991). A critical review of the effect of factory closures on health. Br J Ind Med, 48. p. 1-8.

[29] National Statistics (2003). Better Or Worse: A Longitudinal Study Of The Mental Health Of Adults In Great Britain. 
[30] Nickell S.J. (1979). Education and lifetime patterns of unemployment. Journal of Political Economy, 87. p. 17-32.

[31] Pissarides, C. A. (I98I). 'Staying-on at schoo

[32] Rosenfield S. (1989). The effect of women's employment: personal control and sex difference in mental health. Journal of Health and Social Behaviour, 30. p.77-91

[33] Roskies, E., \& Louis-Guerin, C. (1990). Job insecurity in managers: Antecedents and consequences. Journal of Organizational Behavior, 11, 345-359.

[34] Ross C.E., Mirowsky J., Goldsteen K. (1990). The impact of family on health: The decade in review. Journal of Marriage and the Family, 52. p. 1059-1078.

[35] Roy-Bujnowski K. (2011). Recession, Depression: How The Economy Affects Mental Health. Health \& Fitness. June 8.

[36] Ruhm, C.J. (2000). Are Recessions Good for Your Health? Quarterly Journal of Economics, 115, p. 617-650.

[37] Ruhm, C.J. (2003). Good times make you sick. Journal of Health Economics, 22 (4). p. $637-658$.

[38] Ruhm, C.J. (2005). Healthy living in hard times. Journal of Health Economics, 24 (2). p. 341-363.

[39] Salm M. (2009). Does job loss cause ill health? Health Economics, 18. p. 1075-1089.

[40] Simon, R. W. (1997). The Meanings Individuals Attach to Role Identities and Their Implications for Mental Health. Journal of Health and Social Behavior, 38 (3). p. 256-274.

[41] Schmitz H. (2011). Why are the unemployed in worse health? The causal effect of unemployment on health. Labour Economics, 18. p. 71-78

[42] Shields M., Wheatley Price S., Wooden M. (2009). Life Satisfaction and the Economic and Social Characteristics of Neighbourhoods", Journal of Population Economics, 22. p. $421-443$.

[43] Shields M., Wheatley Price S. (2005). Exploring the Economic and Social Determinants of Psychological and Psychosocial Health. Journal of the Royal Statistical Society, 168. p. 513-538.

[44] Stutzer A., Lalive R. (2004). The role of social work norms in job searching and subjective well-being. Journal of the European Economic Association, 2. p. 696-719.

[45] Sullivan D., von Wachter T. (2009). Job displacement and mortality: an analysis using administrative data. Quarterly Journal of Economics, 124(3). p.1265-1306.

[46] Tefft N. (2011a). Insights on unemployment, unemployment insurance, and mental health. Journal of Health Economics, 30. p. 258-264. 
[47] Tefft N. (2011b). Mental health and employment: The SAD story. Economics and Human Biology (in press).

[48] The Office for National Statistics Psychiatric Morbidity report, 2001

[49] Theodossiou, I. (1998). The effects of low-pay and unemployment on psychological well-being: a logistic regression approach. Journal of Health Economics, 17(1). p.85104.

[50] Warr P., Jackson P., Banks M. (1998). Unemployment and Mental Health: Some British Studies Journal of Social Issues, 44(4). p. 47-68.

[51] Whittaker W., Sutton M. (2010). Mental health, work incapacity and State transfers: an analysis of the British Household Panel Survey. HEDG Working Paper 10/21. University of York.

[52] Zick C.D., Smith K.R. (1991). Marital transitions, poverty, and gender differences in mortality. Journal of Marriage and the Family, 53. p.327-336.

\section{A Appendix}

\section{A.1 Unemployment rate}
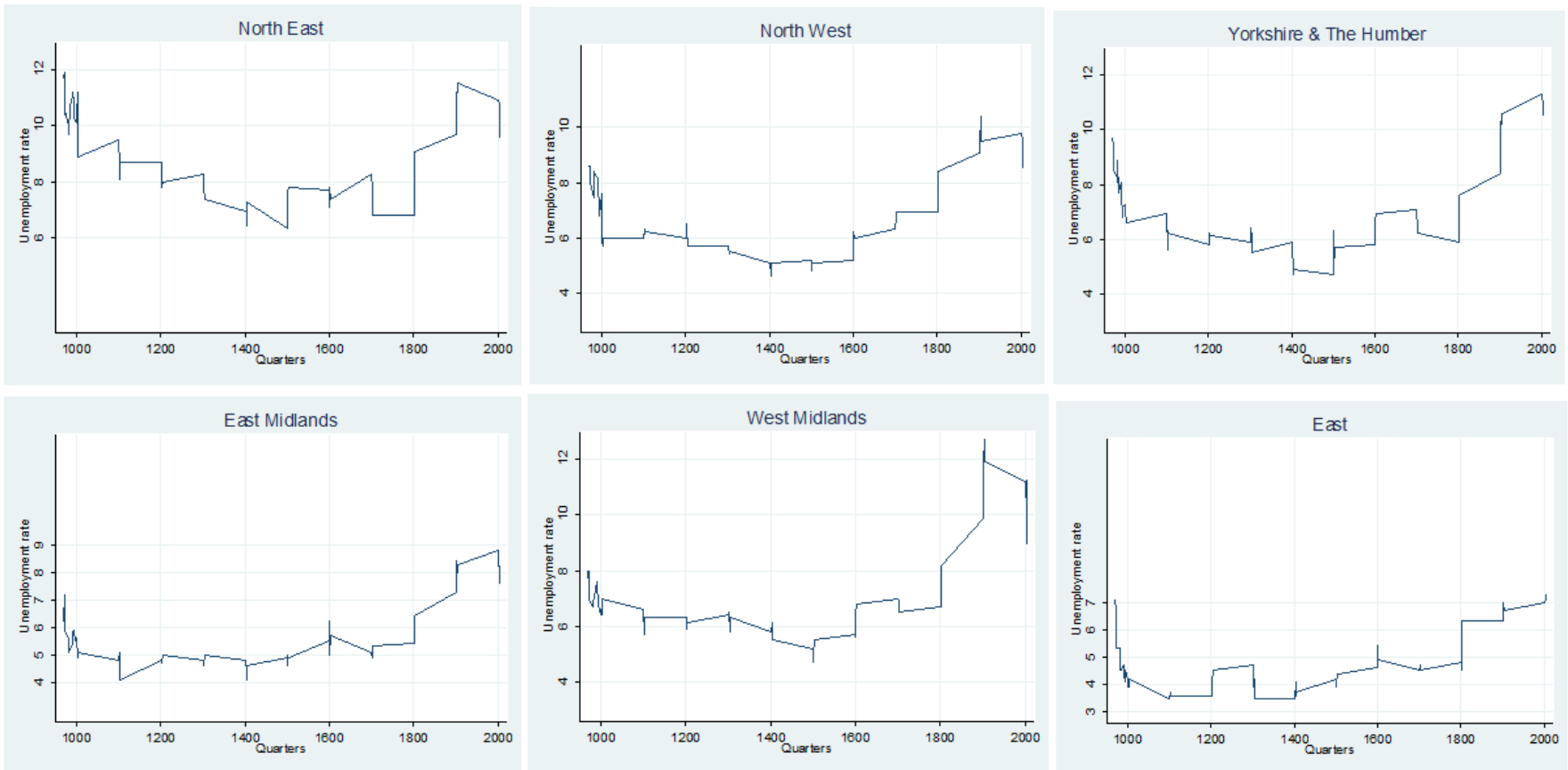

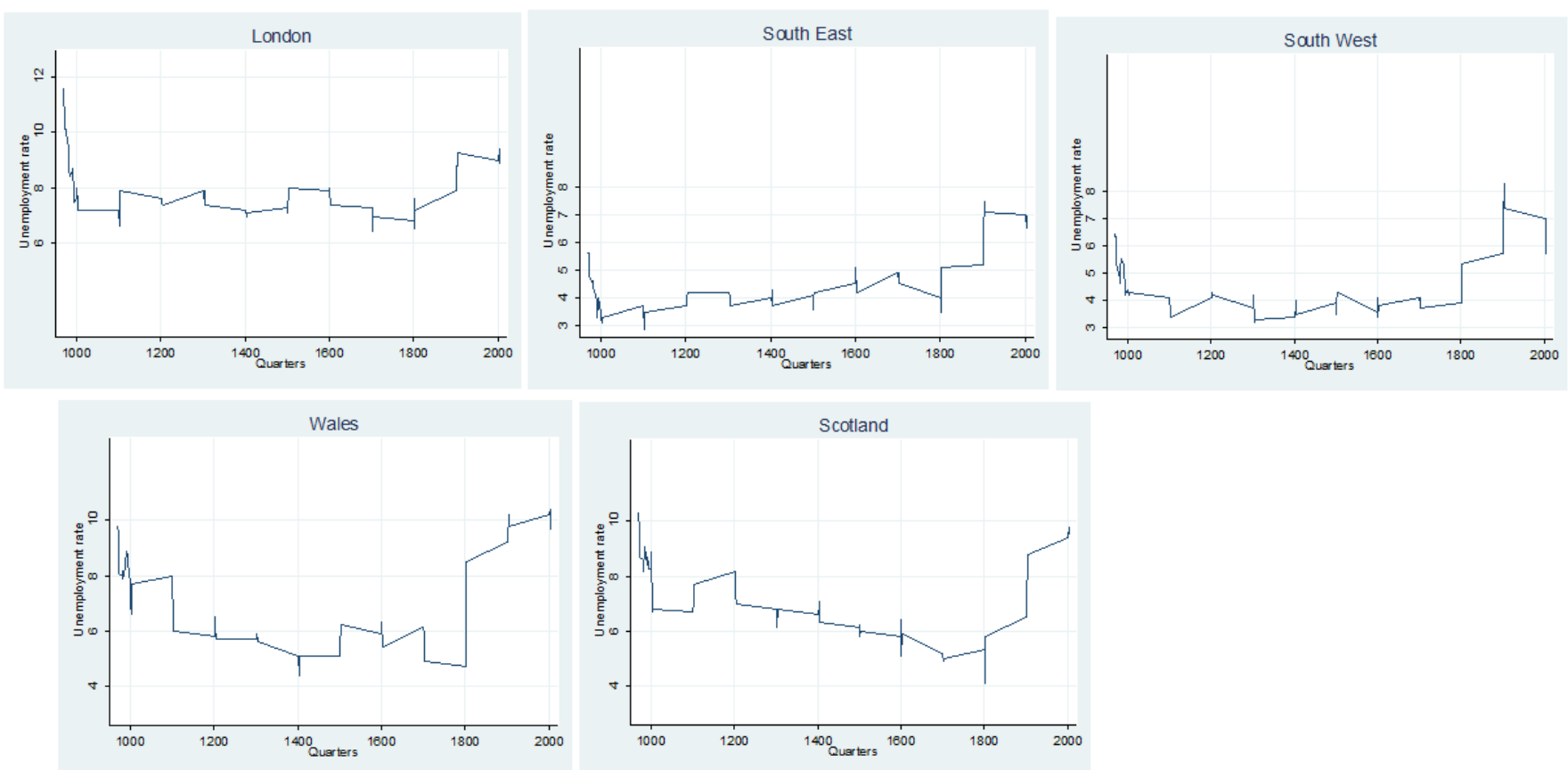

Table 1.2 Unemployment rate correlations

\begin{tabular}{lcccccccc}
\hline & \multicolumn{3}{c}{ Male } & & \multicolumn{5}{c}{ Female } \\
& $\mathrm{t}$ & $\mathrm{t}+1$ & $\mathrm{t}+2$ & $\mathrm{t}+3$ & $\mathrm{t}$ & $\mathrm{t}+1$ & $\mathrm{t}+2$ & $\mathrm{t}+3$ \\
\hline $\mathrm{t}+1$ & 0.9610 & & & & 0.9273 & & & \\
$\mathrm{t}+2$ & 0.9282 & 0.9622 & & & 0.8839 & 0.9266 & & \\
$\mathrm{t}+3$ & 0.8845 & 0.9299 & 0.9635 & & 0.8487 & 0.8852 & 0.9276 & \\
Year avrg & 0.9652 & 0.9861 & 0.9869 & 0.9681 & 0.9515 & 0.9719 & 0.9717 & 0.9518 \\
$\mathrm{~N}$ & \multicolumn{3}{c}{550,661} & & \multicolumn{5}{c}{632,719} \\
\hline
\end{tabular}

Note: $\mathrm{t}$ refers to a quarter ending with a survey month, $\mathrm{t}+1$ refers to a quarter ending three months before the survery month, $t+2$ refers to a quater ending six months before the survery month, $t+3$ refers to a quarter ending nine months before the survey date. Year avrg refers to the $t, t+1, t+2$, and $t+3$ average.

\section{A.2 Results}


Table 7. Coefficients. Probit and Logit

\begin{tabular}{|c|c|c|c|c|c|c|c|c|}
\hline & \multicolumn{4}{|c|}{ Male } & \multicolumn{4}{|c|}{ Female } \\
\hline & \multicolumn{2}{|c|}{ Probit } & \multicolumn{2}{|c|}{ Logit } & \multicolumn{2}{|c|}{ Probit } & \multicolumn{2}{|c|}{ Logit } \\
\hline & All Unempl. & Red. Unempl. & All Unempl. & Red. Unempl. & All Unempl. & Red. Unempl. & All Unempl. & Red. Unempl. \\
\hline Reg. unemployment rate & $0,01577^{* * *}$ & $0,01406^{* *}$ & $0,04243^{* * *}$ & $0,03653^{* *}$ & $0,01782^{* *}$ & $0,01779^{*}$ & $0,04629^{* *}$ & $0,04640^{* *}$ \\
\hline (Employed) & $(0,00601)$ & $(0,00630)$ & $(0,01546)$ & $(0,01663)$ & $(0,00898)$ & $(0,00917)$ & $(0,02261)$ & $(0,02350)$ \\
\hline Reg. unemployment rate & $-0,01187$ & $-0,00973$ & $-0,02022$ & $-0,02527$ & 0,00909 & $0,04649^{*}$ & 0,01427 & 0,09411 \\
\hline (Unemployed) & $(0,00756)$ & $(0,01406)$ & $(0,01766)$ & $(0,03167)$ & $(0,01230)$ & $(0,02643)$ & $(0,02862)$ & $(0,06038)$ \\
\hline \multirow[t]{2}{*}{ Unemployment dummy } & $0,87474^{* * *}$ & $0,58764^{* * *}$ & $2,05225^{* * *}$ & $1,45621^{* * *}$ & $0,59089 * * *$ & 0,16367 & $1,43415^{* * *}$ & 0,49124 \\
\hline & $(0,05072)$ & $(0,11017)$ & $(0,11097)$ & $(0,24864)$ & $(0,05302)$ & $(0,14786)$ & $(0,11635)$ & $(0,33520)$ \\
\hline \multirow[t]{2}{*}{ Age } & $0,05908^{* * *}$ & $0,05241^{* * *}$ & $0,15315^{* * *}$ & $0,14455^{* * *}$ & $0,05054^{* * *}$ & $0,05107^{* * *}$ & $0,12473^{* * *}$ & $0,13121^{* * *}$ \\
\hline & $(0,00650)$ & $(0,00714)$ & $(0,01667)$ & $(0,01931)$ & $(0,00578)$ & $(0,00588)$ & $(0,01460)$ & $(0,01513)$ \\
\hline \multirow[t]{2}{*}{ Age2 } & $-0,00052^{* * *}$ & $-0,00042^{* * *}$ & $-0,00137^{* * *}$ & $-0,00118^{* * *}$ & $-0,00051^{* * *}$ & $-0,00051^{* * *}$ & $-0,00124^{* * *}$ & $-0,00131^{* * *}$ \\
\hline & $(0,00008)$ & $(0,00009)$ & $(0,00020)$ & $(0,00023)$ & $(0,00007)$ & $(0,00007)$ & $(0,00019)$ & $(0,00019)$ \\
\hline \multirow[t]{2}{*}{ Education: Degree } & $-0,15129^{* * *}$ & $-0,16292^{* * *}$ & $-0,36891^{* * *}$ & $-0,41359^{* * *}$ & $-0,24073^{* * *}$ & $-0,22984^{* * *}$ & $-0,59644^{* * *}$ & $-0,57924^{* * *}$ \\
\hline & $(0,02079)$ & $(0,02279)$ & $(0,05239)$ & $(0,05945)$ & $(0,01728)$ & $(0,01823)$ & $(0,04219)$ & $(0,04572)$ \\
\hline \multirow[t]{2}{*}{ Education: Higher } & $-0,10321^{* * *}$ & $-0,11319^{* * *}$ & $-0,24418^{* * *}$ & $-0,28320^{* * *}$ & $-0,09937^{* * *}$ & $-0,09260 * * *$ & $-0,24603^{* * *}$ & $-0,23490^{* * *}$ \\
\hline & $(0,02275)$ & $(0,02429)$ & $(0,05739)$ & $(0,06319)$ & $(0,01753)$ & $(0,01783)$ & $(0,04336)$ & $(0,04482)$ \\
\hline \multirow[t]{2}{*}{ Education: Alevel } & $-0,13969^{* * *}$ & $-0,16779^{* * *}$ & $-0,33970^{* * *}$ & $-0,43822^{* * *}$ & $-0,07840^{* * *}$ & $-0,07517^{* * *}$ & $-0,18878^{* * *}$ & $-0,18772^{* * *}$ \\
\hline & $(0,01962)$ & $(0,02173)$ & $(0,04889)$ & $(0,05632)$ & $(0,01573)$ & $(0,01698)$ & $(0,03788)$ & $(0,04226)$ \\
\hline \multirow[t]{2}{*}{ Education: Olevel } & $-0,03288$ & $-0,04927^{* *}$ & $-0,07060$ & $-0,12407^{* *}$ & $-0,10787^{* * *}$ & $-0,11270^{* * *}$ & $-0,26016^{* * *}$ & $-0,28374^{* * *}$ \\
\hline & $(0,02189)$ & $(0,02355)$ & $(0,05513)$ & $(0,06094)$ & $(0,01547)$ & $(0,01607)$ & $(0,03784)$ & $(0,04031)$ \\
\hline \multirow[t]{2}{*}{ Education: Other } & $-0,03297$ & $-0,04938^{*}$ & $-0,07788$ & $-0,13283^{* *}$ & $-0,03795^{* *}$ & $-0,03687^{*}$ & $-0,09190^{* *}$ & $-0,09431^{* *}$ \\
\hline & $(0,02355)$ & $(0,02558)$ & $(0,05829)$ & $(0,06621)$ & $(0,01737)$ & $(0,01906)$ & $(0,04148)$ & $(0,04721)$ \\
\hline \multirow[t]{2}{*}{ Married } & $-0,22090^{* * *}$ & $-0,22606^{* * *}$ & $-0,55229^{* * *}$ & $-0,59340^{* * *}$ & $-0,23525^{* * *}$ & $-0,22584^{* * *}$ & $-0,58851^{* * *}$ & $-0,57458^{* * *}$ \\
\hline & $(0,01192)$ & $(0,01293)$ & $(0,03011)$ & $(0,03341)$ & $(0,01169)$ & $(0,01236)$ & $(0,02852)$ & $(0,03066)$ \\
\hline \multirow[t]{2}{*}{ Children dummy } & $-0,06873^{* * *}$ & $-0,05039^{* * *}$ & $-0,19503^{* * *}$ & $-0,14314^{* * *}$ & $-0,06955^{* * *}$ & $-0,05869^{* * *}$ & $-0,18515^{* * *}$ & $-0,15530^{* * *}$ \\
\hline & $(0,01247)$ & $(0,01299)$ & $(0,03249)$ & $(0,03473)$ & $(0,00906)$ & $(0,00932)$ & $(0,02279)$ & $(0,02366)$ \\
\hline \multirow[t]{2}{*}{ Constant } & $-4,02150^{* * *}$ & $-3,87726^{* * *}$ & $-9,01073^{* * *}$ & $-8,85330^{* * *}$ & $-3,59674^{* * *}$ & $-3,61816^{* * *}$ & $-7,76521^{* * *}$ & $-7,94770^{* * *}$ \\
\hline & $(0,15315)$ & $(0,16651)$ & $(0,39332)$ & $(0,45147)$ & $(0,12379)$ & $(0,12611)$ & $(0,31263)$ & $(0,32479)$ \\
\hline $\mathrm{N}$ & 550,661 & 531,133 & 550,661 & 531,133 & 632,129 & 612,116 & 632,129 & 612,116 \\
\hline
\end{tabular}


Table 8.1. Summary statistics. Married Male

\begin{tabular}{|c|c|c|c|c|c|c|c|c|}
\hline \multirow[b]{2}{*}{ Sample } & \multicolumn{4}{|c|}{ Known empl.status of spouse } & \multicolumn{4}{|c|}{ Unknown empl.status of spouse } \\
\hline & Mean & Std.dev. & Min & Max & Mean & Std.dev. & Min & Max \\
\hline Depression/Anxiety & 0.92 & 0.95 & 0 & 1 & 0.85 & 0.91 & 0 & 1 \\
\hline Unemployment rate (regional) & 4.15 & 1.99 & 2.9 & 12.7 & 1.76 & 1.31 & 2.9 & 12.7 \\
\hline Unemployment rate (in sample) & 6.26 & 1.90 & 0 & 1 & 6.19 & 1.90 & 0 & 1 \\
\hline Age & 41.61 & 7.71 & 25 & 54 & 42.21 & 7.69 & 25 & 54 \\
\hline Degree & 23.93 & 4.26 & 0 & 1 & 23.18 & 4.22 & 0 & 1 \\
\hline Higher & 10.56 & 3.07 & 0 & 1 & 11.32 & 3.16 & 0 & 1 \\
\hline Alevel & 28.21 & 4.50 & 0 & 1 & 31.50 & 4.64 & 0 & 1 \\
\hline Olevel & 16.50 & 3.71 & 0 & 1 & 16.24 & 3.68 & 0 & 1 \\
\hline Other qualification & 12.96 & 3.35 & 0 & 1 & 11.69 & 3.21 & 0 & 1 \\
\hline No qualification & 7.81 & 2.68 & 0 & 1 & 6.05 & 2.38 & 0 & 1 \\
\hline Having a child & 60.12 & 4.89 & 0 & 1 & 53.39 & 4.98 & 0 & 1 \\
\hline $\mathrm{N}$ & \multicolumn{4}{|c|}{193,98} & \multicolumn{4}{|c|}{152,064} \\
\hline
\end{tabular}

Table 8.2. Summary statistics. Married Female

\begin{tabular}{|c|c|c|c|c|c|c|c|c|}
\hline \multirow[b]{2}{*}{ Sample } & \multicolumn{4}{|c|}{ Known empl.status of spouse } & \multicolumn{4}{|c|}{ Unknown empl.status of spouse } \\
\hline & Mean & Std.dev. & Min & Max & Mean & Std.dev. & Min & Max \\
\hline Depression/Anxiety & 1.22 & 1.10 & 0 & 1 & 1.31 & 1.13 & 0 & 1 \\
\hline Unemployment rate (regional) & 3.06 & 1.72 & 2.2 & 9.5 & 2.07 & 1.42 & 2.2 & 9.5 \\
\hline Unemployment rate (in sample) & 4.96 & 1.19 & 0 & 1 & 4.95 & 1.19 & 0 & 1 \\
\hline Age & 41.13 & 7.63 & 25 & 54 & 41.39 & 7.89 & 25 & 54 \\
\hline Degree & 17.79 & 3.82 & 0 & 1 & 20.44 & 4.03 & 0 & 1 \\
\hline Higher & 13.04 & 3.36 & 0 & 1 & 13.77 & 3.44 & 0 & 1 \\
\hline Alevel & 16.86 & 3.74 & 0 & 1 & 16.15 & 3.68 & 0 & 1 \\
\hline Olevel & 29.80 & 4.57 & 0 & 1 & 27.49 & 4.46 & 0 & 1 \\
\hline Other qualification & 12.78 & 3.33 & 0 & 1 & 12.92 & 3.35 & 0 & 1 \\
\hline No qualification & 9.70 & 2.96 & 0 & 1 & 9.20 & 2.89 & 0 & 1 \\
\hline Having a child & 59.28 & 4.91 & 0 & 1 & 50.51 & 4.99 & 0 & 1 \\
\hline $\mathrm{N}$ & \multicolumn{4}{|c|}{272,712} & \multicolumn{4}{|c|}{163,806} \\
\hline
\end{tabular}




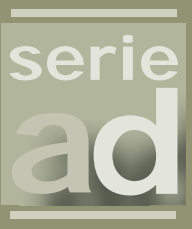

\section{I vie}

Guardia Civil, 22 - Esc. 2, 1o

46020 Valencia - Spain

Phone: +34963190050

Fax: +34 963190055

Department of Economics

University of Alicante

Campus San Vicente del Raspeig

03071 Alicante - Spain

Phone: +34965 903563

Fax: +34965903898

Website: www.ivie.es

E-mail: publicaciones@ivie.es 